\title{
Phenol and Flavonoid Amounts, Antioxidant and Antibacterial Potencies of Xanthoparmelia stenophylla (Ach.) Ahti\&D. Hawksw.
}

\author{
Kadir KINALIOĞLU ${ }^{1}$, Sinem AYDIN ${ }^{1}$, Özge iLHAN ${ }^{1}$, Zeynep YILMAZ ${ }^{1}$ \\ Giresun University, Department of Biology, Faculty of Science and Arts, 28200, Giresun, Turkey \\ e-posta: sinem.aydin@giresun.edu.tr
}

Geliş Tarihi:01.12.2015; Kabul Tarihi:03.03.2016

\begin{abstract}
Keywords

Xanthoparmelia

stenophylla; Lichen;

Antimicrobial activity;

Antioxidant

Xanthoparmelia stenophylla is traditionally utilized for the cure of snake bites and venearal diseases like syphilis. $X$. stenophylla have different colouring compounds and can be used as dye sources. Different extracts obtained from $X$. stenophylla were tested in terms of antioxidant and antibacterial traits. Phenol and flavonoid concentrations of the extracts were also determined. Chloroform and acetone were used as solvents in the soxhlet extraction. While bacteria-inhibiting efficacy was detected with the disc diffusion technique. The antioxidant property was determined through DPPH radical scavenging activity, reducing power and metal chelating activity. Chloroform extract was most effective against Bacillus megaterium with an inhibition zone of $25 \mathrm{~mm}$. Both the acetone and chloroform extracts were not effective against Klebsiella pneumonia. The highest phenolic content was found in the chloroform extract $(42.58 \pm 0.47 \mu \mathrm{g} / \mathrm{mL})$ and the highest flavonoid content was obtained in the acetone extract $(113.56 \pm 1.02 \mu \mathrm{g} / \mathrm{mL})$. DPPH activity of lichen extracts was between $9.33-33.84 \%$. The reducing activity extracts and standards were found the given order: $\mathrm{BHT}>\mathrm{Rutin}>$ Chloroform extract of $X$. stenophylla> Acetone extract of $X$. stenophylla. In the study, it was seen that X. stenophylla can probably be an alternative to the other natural antioxidant and antibacterial agents.
\end{abstract}

\section{Xanthoparmelia stenophylla (Ach.) Ahti\&D. Hawksw. Likeninin Fenol ve Flavonoid Miktarları, Antioksidan ve Antimikrobiyal Potansiyelleri}

Özet

Xanthoparmelia stenophylla geleneksel olarak yılan sokması ve frengi gibi zührevi hastalıkların tedavisinde kullanılmaktadır. $X$. stenophylla değişik renk maddelerine sahiptir ve boya kaynağı olarak da kullanılabilmektedir. $X$. stenophylla'dan elde edilmiş farklı ekstraktlar antioksidan ve antibakteriyal özellikleri bakımından test edildi. Ekstraktların fenol ve flavonoid konsantrasyonları da belirlendi. Soksalet ekstraksiyonunda kloroform ve aseton kullanıldı. Bakteri inhibe etme aktivitesi disk difüzyon metoduyla belirlenirken antioksidan özelliği DPPH radikal süpürme aktivitesi, indirgeme gücü, metal şelatlama aktivitesi ile belirlendi. Kloroform ekstraktı en çok Bacillus megaterium'a karşı 25 mm'lik zon inhibisyonu gösterdi. Aseton ve kloroform ekstraktlarının her ikisi de Klebsiella pneumoniae'ye karşı etki göstermedi. En yüksek fenolik içerik kloroform ekstraktında bulundu $(42.58 \pm 0.47 \mu \mathrm{g} / \mathrm{mL})$. Ekstraktların DPPH aktivitesi \%9.33-33.84 arasındaydı. Ekstraktların ve standartların indirgeme gücü BHT>Rutin $>X$. stenophylla'nın kloroform ekstraktı $X X$. stenophylla'nın aseton ekstraktı şeklinde bulundu. Çalışmada, $X$. stenophylla'nın diğer doğal antioksidan ve antibakteriyal ajanlara bir alternatif olabileceği görüldü. 


\section{Introduction}

Biological combustion causes deleterious products called reactive oxygen species (ROS) (Sen et al., 2010). ROS are chemically so reactive that they gives the rise to lipid peroxidation and effects to DNA. Antioxidant regularity of the cell reducesthis mess created by ROS (Mates, 2000). Accordingly, the balance between ROS and antioxidants is fundamental for protecting a healthy biological system (Sen et al., 2010).

Lately, antibiotic resistant to clinically important pathogens has been a common problem worldwide. Due to the high cost and ineffectiveness against pathogens of new generation antibiotics, there has been a deep interest for studying effective antimicrobial agents from different sources such as plants (Akinsulure et al., 2007).

Lichen is a combination of a heterotroph mycobiont and autotroph photobiont, which live together symbiotically. They are used for the perfume industry and as a dye source as well as for air pollution monitoring and a cure for illnesses of humans. Lichens have many significant actions including antioxidant, antibacterial, anti herbivore, analgesic, antipyretic and antiinflammatory activities (Srivastava et al., 2013). Antioxidant and antimicrobial activities of lichen samples have been confirmed by many investigators (Pavithra et al., 2013; Thippeswamy et al., 2013; Vattem et al., 2012).

X. stenophylla a common foliose lichen species growing on sunny boulders and outcorps. Thallus of the species contains salazinic acid, consalazinic acid and sometimes with lobaric acid (Brodo et. al, 2001). In traditional medicine, $X$. stenophylla is used for treating snake bites and is applied to cure venearal diseases like syphilis. Xanthoparmelia have different colouring compounds and can be used as dye sources. Moreover, Xanthoparmelia result in less erosive activities and animal hurting in the forest (Haq et al., 2012).

In accordance with the above mentioned facts, in this survey antioxidant and antibacterial properties of different extracts of $X$. stenophylla were examined.

\section{Material and Methods}

\subsection{Collecting of Lichen for Bioassays}

$X$. stenophylla was collected from Gedikkaya hill of Giresun province in 2011. Lichen sample was identified using Brodo et al. (2001). The identified samples is kept in the herbarium of Giresun University (Herbarium no: 2391).

\subsection{Growth and Conservation of Bacterial Strains for Antibacterial Surveys}

A total of seven strains of bacteria were utilized to assess the antibacterial activity of lichen samples. Klebsiella pneumoniae ATCC 13385, Proteus vulgaris ATCC 7829, Bacillus megaterium (laboratory isolate), Staphylococcus cohnii (laboratory isolate) were obtained from Genetics and Bioengineering Department of Yeditepe University; Staphylococcus aureus subsp. aureus ATCC 25923 was obtained from Control Laboratory in Giresun province; Escherichia coli ATCC 35218 was obtained from Biology Department of Giresun University and Bacillus cereus 702 ROMA was obtained from Molecular Biology Department of Rize University. Bacterial strains were maintained on nutrient agar at $4{ }^{\circ} \mathrm{C}$.

\subsection{Extraction Procedure for Crude Extracts}

Before the extraction was carried out, lichen was cleaned and dried at the room temperature. It was pulverized with a blender. $48 \mathrm{~g}$ of powdery lichen samples was extracted separately with 480 $\mathrm{mL}$ acetone or chloroform for $7 \mathrm{~h}$ with a Soxhlet extractor. Extracts were filtered with Whatman paper. Solvents were evaporated with a rotary evaporator (Kumar et al., 2012) During the experiments, the mentioned extracts were 
dissolved in dimethyl sulfoxide (DMSO).

\subsection{Antibacterial Influence}

\subsubsection{Disc Diffusion Experiment}

Disc diffusion method was applied by utilizing the Kirby-Bauer technique to establish the antibacterial influence (Bauer et al., 1996). Extracts were prepared with DMSO. Overnight bacterial cultureswere prepared in the Mueller Hinton broth. Cultures were spread to the whole surface of the Mueller Hinton agar in a petri with sterile swab and then allowed to dry. Sterile discs ( $5 \mathrm{~mm}$ diameter) were saturated with $20 \mu \mathrm{L}$ of extracts of $X$. stenophylla, separately and put on the agar surface. DMSO $(20 \mu \mathrm{L})$, tetracycline (30 $\mu \mathrm{g} / \mathrm{mL})$ and gentamicin $(10 \mu \mathrm{g} / \mathrm{mL})$ were used as controls. These were incubated at $37^{\circ} \mathrm{C}$ for $24 \mathrm{~h}$. Inhibition zones at around of discs were recorded in millimeters.

\subsubsection{Minimal Inhibition Concentration (MIC)}

In minimal inhibition assay, macrobroth dilution method was used. Tubes were prepared by dispensing into each tube $950 \mu \mathrm{L}$ of Mhüller Hinton Broth and $50 \mu \mathrm{L}$ of the inoculum. Then, $1000 \mu \mathrm{L}$ of lichen extract $(30 \mathrm{mg} / \mathrm{mL}$ concentration) was added to the first tube. 1000 $\mu \mathrm{L}$ suspension was transferred into the consecutive tubes to get serial dilutions. The last tube containing $1950 \mu \mathrm{L}$ of nutrient broth without compound and inoculum was used as negative control. The tubes were incubated at $37{ }^{\circ} \mathrm{C}$ overnight (Yiğit et al., 2009).

\subsection{Antioxidant Activity}

DPPH radical scavenging, reducing power, metal chelating activity, ABTS radical scavenging activity, total phenolic content and total flavonoid content were performed to determine the antioxidant ability of lichen extracts. All the analyses were applied as triplicate. The values are expressed as mean $\pm S D$ of triplicate estimation.

\subsubsection{Total Phenolic Content}

Total phenolic contents of lichens were determined in accordance with the method of Slinkard and Singleton (1977) utilizing gallic acid standard. Shortly, $0.1 \mathrm{~mL}$ lichen extract in DMSO was diluted with $4.5 \mathrm{~mL}$ distilled water. Then, 0.1 $\mathrm{mL}$ Folin-Ciocalteu reagent (previously diluted 3fold with distilled water) was put into the mixture. After 3 minutes, $0.3 \mathrm{~mL} \mathrm{Na} \mathrm{CO}_{3}(2 \%)$ was added. The absorbance was measured at $760 \mathrm{~nm}$, after incubating the mixture for $90 \mathrm{~min}$. The quantity of the total phenolic compounds was denoted as $\mathrm{mg}$ of gallic acid equivalent (GAE), ( $\left.R^{2}: 0.995\right)$.

\section{Absorbance: $0.002 x$ Total phenolic content ( $\mu$ g gallic acid equivalent)

\subsubsection{Total Flavonoid Content}

Total flavonoids of lichen were determined by the procedure of Zhishen et al. (1999). $0.25 \mathrm{~mL}$ lichen extract in DMSO was added to $1.25 \mathrm{~mL}$ distilled water followed by $75 \mu \mathrm{L} \mathrm{NaNO}_{2}$ (\%5) and incubated for $5 \mathrm{~min}$. Afterwards, $150 \mu \mathrm{L} \mathrm{AlCl}_{3} \cdot 6 \mathrm{H}_{2} \mathrm{O}$ (\%10) was incorporated to the mixture and further incubated for $5 \mathrm{~min}$, the reaction mixture was treated with $0.5 \mathrm{~mL} \mathrm{NaOH}(1 \mathrm{M})$ and $275 \mu \mathrm{L}$ distilled water. It was measured spectrometrically at $510 \mathrm{~nm}$. The amount of total flavonoid compounds was calculated as $\mathrm{mg}$ of catechin equivalents ( $Q E$ ) by using an equation that has been obtained from the rutin calibration curve $\left(R^{2}\right.$ : 0.982).

Absorbance: $0.001 \times$ Total flavonoid content ( $\mu$ g cateschin equivalent)

\subsubsection{DPPH Radical Scavenging Activity}

DPPH radical scavenging activity of $X$. stenophylla extracts was established by 1,1-diphenyl-2-picrylhydrazyl (DPPH) (Blois, 1958). Appropriate dilution series $(250-1000 \mu \mathrm{g} / \mathrm{mL})$ were prepared for lichen extracts in DMSO. $0.75 \mathrm{~mL}$ of each solution was added to $1.5 \mathrm{~mL}$ of a $6 \times 10^{-5} \mathrm{M}$ methanolic solution of DPPH. The mixture was stirred vigorously and 
allowed to stand in the dark at the room temperature for $30 \mathrm{~min}$. Decrease in absorbance of the solution against methanol was measured at $517 \mathrm{~nm}$ with a Shimadzu 1240 UV-Vis spectrophotometer.

The DPPH radical scavenging activity was calculated using the following equation:

$D P P H$ radical scavenging activity (\%):

$=\left(\frac{\mathrm{ABS} \text { of the control }-\mathrm{ABS} \text { of the sample }}{\mathrm{ABS} \text { of the control }}\right) \times 100$

Synthetic antioxidant reagents BHT, ascorbic acid and rutin were used as positive control.

\subsubsection{ABTS Radical Scavenging Activity}

The stock solution was obtained by mixing equal quantities of $7.4 \mathrm{mM} \mathrm{ABTS}{ }^{+}$solution and $2.6 \mathrm{mM}$ potassium persulfate solution and then standing for 12 hours at room temperature in the dark. The solution was then diluted by mixing $1 \mathrm{~mL} \mathrm{ABTS}{ }^{+}$ solution with $60 \mathrm{~mL}$ methanol to get an absorbance of $0.700 \pm 0.02$ units at $734 \mathrm{~nm}$ with the spectrophotometer. $\mathrm{ABTS}^{+}$solution was prepared daily. ABTS radical scavenging assay was carried out mixing $150 \mu \mathrm{L}$ tested lichen sample with 2850 $\mu \mathrm{L}$ of the $\mathrm{ABTS}^{+}{ }^{+}$solution for $2 \mathrm{~h}$ in a dark condition. The absorbance was taken at $734 \mathrm{~nm}$ using the spectrophotometer. This scavenging generates a decline in the absorbance at $734 \mathrm{~nm}$ (Arnao et al., 2001).

The ABTS radical scavenging activity was calculated using the following equation:

ABTS radical scavenging activity (\%)

$=\left(\frac{\mathrm{ABS} \text { of the control }-\mathrm{ABS} \text { of the sample }}{A B S \text { of the control }}\right) \times 100$

Synthetic antioxidant reagents BHT and ascorbic acid were used for control.

\subsubsection{Ferric lons Reducing Antioxidant Power (FRAP)}

The FRAP assay of extracts was performed according to the method given by Oyaizu (1986). Different concentrations of lichen extracts (250$1000 \mu \mathrm{g} / \mathrm{mL}$ ) were added to $2.5 \mathrm{~mL}$ of phosphate buffer $(0.2 \mathrm{M}, \mathrm{pH} 6.6)$ and $2.5 \mathrm{~mL}$ potassium ferricyanide (1\%). This mixture was vortexed vigorously and kept at $50{ }^{\circ} \mathrm{C}$ at water bath for 20 min. After incubation, $2.5 \mathrm{~mL}$ of trichloroacetic acid $(10 \%)$ was added to the mixture and centrifuged at $3000 \mathrm{rpm}$ for $10 \mathrm{~min}$. Whereupon, the supernatant layer $(2.5 \mathrm{~mL})$ was mixed with distilled water $(2.5 \mathrm{~mL})$ and $0.5 \mathrm{~mL} \mathrm{FeCl}(0.1 \%)$. The absorbance was read at $700 \mathrm{~nm}$. Rutin and BHT were used as positive control.

\subsubsection{Metal Chelating Activity}

Determination of chelation of iron (II) ions by acetone and chloroform extracts of $X$. stenophylla in comparison with EDTA (Dinis et al., 1994). $\mathrm{Fe}^{2+}$ chelating ability of lichen extracts and EDTA was monitored by the absorbance of the ferrous ironferrozine complex at $562 \mathrm{~nm}$. Briefly, $5 \mathrm{~mL}$ of lichen extracts (prepared at $250-1000 \mu \mathrm{g} / \mathrm{mL}$ concentrations in DMSO) and $2 \mathrm{mM} \mathrm{FeCl}_{2}(0.1 \mathrm{~mL})$ solution were mixed. After $30 \mathrm{~min}, 5 \mathrm{mM}$ ferrozine $(0.2 \mathrm{~mL})$ was added to the mixture. The mixture was shaken mightily and left at the room temperature for 10 minutes. Absorbance of the solution was read at $562 \mathrm{~nm}$. The iron chelating action was calculated with this equation:

Iron chelating activity(\%)

$=\left(\frac{\mathrm{ABS} \text { of the control }-\mathrm{ABS} \text { of the sample }}{\mathrm{ABS} \text { of the control }}\right) \times 100$

\section{Results and Discussion}

\subsection{Antibacterial Effectiveness}

$0.658 \mathrm{gr}$ crude extract was obtained from acetone extract while 1.0643 gr crude extract was obtained from chloroform extract. 
Inhibition zones of acetone extract ranged from 6 to $21 \mathrm{~mm}$ and the inhibition zones of chloroform extract was ranged from 6 to $25 \mathrm{~mm}$. If the inhibition zones are smaller than $14 \mathrm{~mm}$, it means the relevant microorganism is resistant; however, if the inhibition zones are greater than $17 \mathrm{~mm}$, it means the microorganism is sensitive (Albayrak, 2006). Results acquired in the current study demonstrated that the lichen extracts possess antibacterial activity against gram $+B$. cereus, $B$. megaterium, $S$. cohnii and $S$. aureus subsp. aureus. E. coli and K. pneumoniae was more resistant to the lichen extracts than the other tested bacteria. Gram + and gram - bacteria are shown in the Table 1.

The present study revealed that gram positive bacteria were more susceptible to the tested lichens compared with gram negative bacteria species. The different sensitivity of bacteria can be explained by different cell composition between gram positive and gram negative bacteria.

While the supreme action was recorded against $B$. megaterium by chloroform extract with a $25 \mathrm{~mm}$ inhibition zone, the lowest impact was observed against $S$. cohnii by acetone extract with a $15 \mathrm{~mm}$ inhibition zone. Moreover, chloroform extract was more effective in inhibiting the bacterial growth than acetone extract except for the cases of $P$. vulgaris, E. coliand K. pneumoniae (Table 1). The inhibitory effect of the solvent alone against the microorganisms was zero except for $K$. pneumoniae.

The force of the antimicrobial action changes according to the extract type, extract concentration and tried microorganisms (Srivastava et al., 2013).
Table 1. Results of antibacterial activities of $x$. stenophylla lichen extracts $(\mathrm{mm})$

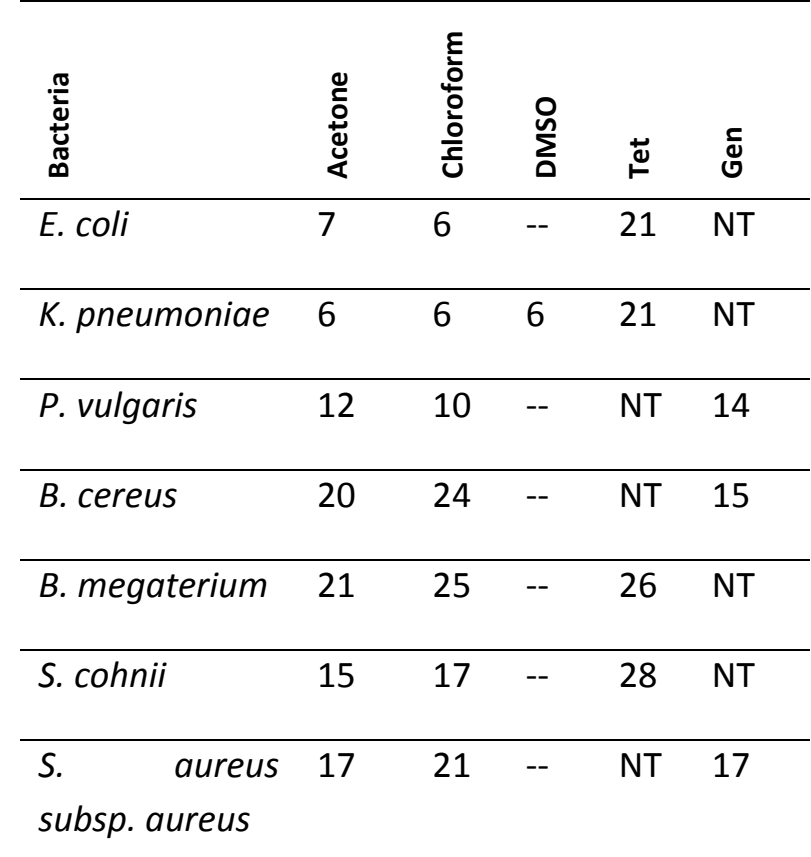

(-): No zone; NT: Not tested; Tetracycline: $30 \mu \mathrm{g} / \mathrm{mL}$; Gentamicin: $10 \mu \mathrm{g} / \mathrm{mL}$

MIC is the least concentration of the extracts that hinder expansion of bacteria and fungi. Definition of MIC is crucial in diagnostic laboratories because it helps in detecting the resistance of microorganism to an antimicrobial agent and it reveals the activity of new antimicrobial agents (Sen and Batra, 2012).

MIC values of lichen extracts are shown in Table 2 . The MIC values of $X$. stenophylla were ranging between $1.875-0,1171875 \mathrm{mg} / \mathrm{mL}$. The lowest MIC value was calculated against $S$. aureus subsp. aureus $(0.1171875 \mathrm{mg} / \mathrm{mL})$.

Table 2. MIC values of lichen extracts $(\mathrm{mg} / \mathrm{mL})$

\begin{tabular}{lll}
\hline Bacteria & $\begin{array}{l}\text { Acetone } \\
\text { extract }\end{array}$ & $\begin{array}{l}\text { Chloroform } \\
\text { extract }\end{array}$ \\
\hline B. cereus & 0.234375 & 0.9375 \\
\hline B. megaterium & 0.46875 & 0.1171875 \\
\hline S. cohnii & 0.234375 & 0.234375 \\
\hline S. aureus & 0.234375 & 0.1171875 \\
& & \\
\hline
\end{tabular}


Houshyar et al. (2014) examined acetone, methanol and chloroform extracts of $X$. stenophylla against two potato rot agents named Fusarium equiseti and Pectobacterium carotovora $p v$. carotovora. Whereas there were no effect against fungi, there were inhibitory effect of methanolic extract of $X$. stenophylla against bacteria.

Zambare et al. (2010) reported that methanol and acetone extracts of $X$. stenophylla (synonym: Xanthoparmelia somloensis) has antimicrobial activity against $S$. aureus, Streptococcus pyogenes and Streptococcus agalactiae but they don't possess any activity against $E$. coli (Zambare et al., 2010). This result is compliant with our study, as well. In our study there was no antibacterial effect of the acetone extract against $E$. coli but there was antibacterial activity against $S$. aureus.

\subsection{Antioxidant Activity}

The phenolic compounds have antioxidant properties because they act as free radical oxidation terminators while flavonoids possess scavenging or chelating action (Atanossova et al., 2011).

Acetone and chloroform extracts were examined for their phenolic and flavonoid amounts (Table 3). The amount of phenolics was established with the equation, which has been acquired from standard gallic acid curve graph. Phenolic content of aseton extract was $32.15 \pm 0.85 \mu \mathrm{g} / \mathrm{mL}$ of GAE while the total phenolic content of chloroform extract was $42.58 \pm 0.47 \mu \mathrm{g} / \mathrm{mL}$ of GAE. Flavonoid quantity was presented with cateshin equivalent (QE) which utilizing an equation which obtained from catechin curve graph. The total flavonoid contents of acetone and chloroform extractswere $113.56 \pm 1.02$ and $24.53 \pm 1.15 \mu \mathrm{g} / \mathrm{mL}$ of catechin equivalent, respectively.
Table 3. Phenolic and flavonoid amounts in the chloroform and acetone extracts of $X$. stenophylla

\begin{tabular}{lll}
\hline $\begin{array}{l}\text { Lichen } \\
\text { extract }\end{array}$ & $\begin{array}{l}\text { Total phenolic } \\
\text { content }(\mu \mathrm{g} / \mathrm{mL} \\
\text { of GAE) }\end{array}$ & $\begin{array}{l}\text { Total } \\
\text { flavonoid } \\
\text { content } \\
(\mu \mathrm{g} / \mathrm{mL} \text { of QE) }\end{array}$ \\
\hline Acetone & $32.15 \pm 0.85$ & $113.56 \pm 1.02$ \\
\hline Chloroform & $42.58 \pm 0.47$ & $24.53 \pm 1.15$ \\
\hline
\end{tabular}

A great deal of investigators found a relation between the antioxidant activity and phenolic content (Jeetendra and Manish, 2011; Piluzza and Bullitta, 2011). Curiously, Rekika et al. (2005) studied selected strawberry genotypes and according to this study, there wasn't any relation between individual phenolic compound and the total antioxidant activity (Rekika et al., 2005).

DPPH method is a fast, easy and reliable method and does not necessitate a special device. DPPH is a stable and synthetic radical. A solution of DPPH radicals prepared in methanol is converted into DPPH-H (diphenylhydrazine) molecules in the existence of an antioxidant agent. Discoloration of DPPH reflects the radical scavenging ability of analyzed samples (Aksoy et al., 2013). The scavenging DPPH radical of tested extracts is summarized as inhibition (\%) Figure 1. Chloroform extract showed better activity than acetone extract. The scavenging effects of lichen extracts were between 9.33 - 33.84\%. Extracts of lichen were showed weaker activity than positive controls.

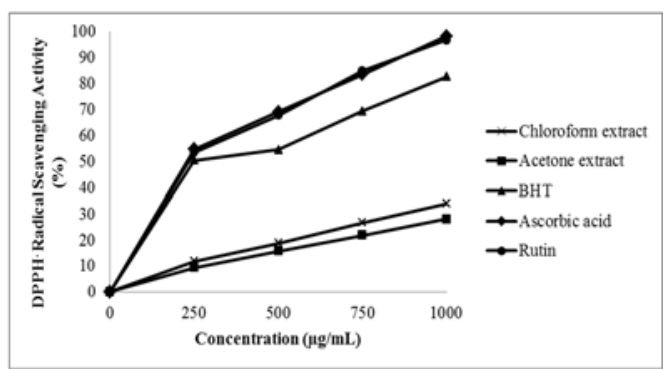

Figure 1. DPPH radical scavenging activity of extracts of $X$. stenophylla and standards 
Zambare et al. (2010) examined antioxidant activity of $X$. somloensis which is synonym of $X$. stenophylla. It was concluded that $X$. stenophylla exhibited DPPH radical scavenging and lipid peroxidation activity.

The results of ABTS radical scavenging activity of extracts are introduced in Figure 2. Amongst tried lichen extracts, chloroform extract has supreme $\mathrm{ABTS}^{+}$scavenging activity, though the activity was lower when compared with BHT and ascorbic acid.

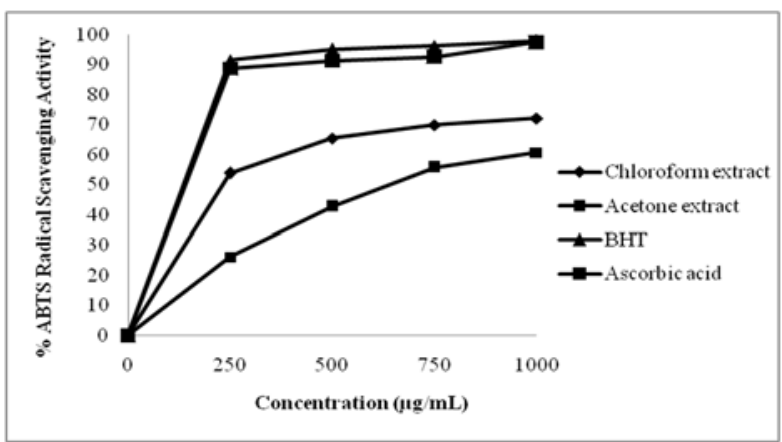

Figure 2. ABTS radical scavenging activity of lichen extracts and standards

Kumar et al. (2014) carried out the study antioxidant activity of water, methanol and nhexane extracts of $X$. stenophylla lichen. According this study, methanolic extract of $X$. stenophylla showed the highest ABTS radical scavenging activity among the other tested lichen. $\mathrm{N}$-hexane extract of lichen showed higher activity than the methanolic and water extracts. Moreover, all of the extracts of $X$. stenophylla exhibited ferric reducing antioxidant power and nitric oxide scavenging activity.

The reducing traits are related to reductones. Gordon (1990) declared that the antioxidant characteristics of reductones are attributed to distruption of free chain by giving a hydrogen atom (Gordon, 1990). Ferric ions reducing antioxidant power of standards, acetone and chloroform are shown in Figure 3. The highest reducing power was detected for $\mathrm{BHT}(1.841 \mathrm{~nm})$ and the lowest reducing power was detected for acetone $(0.142 \mathrm{~nm})$. Higher absorbance of reaction mixture, indicated that the reducing power is increased. The reducing activity of extracts follows the given order: BHT > Rutin > CXS $>$ AXS.



Figure 3. Ferric ions reducing antioxidant powerof extracts of $X$. stenophylla and standards

The metal chelating action of $X$. stenophylla were determined in accordance with the method of (Dinis et al., 1994). Ferrozine may quantitavely form complexes with $\mathrm{Fe}^{2+}$. On the other hand, in the occurrence of chelating agents, the complex creation is disrupted and the red colour of the complex is decreased (Ebrahimzadeh et al., 2008).

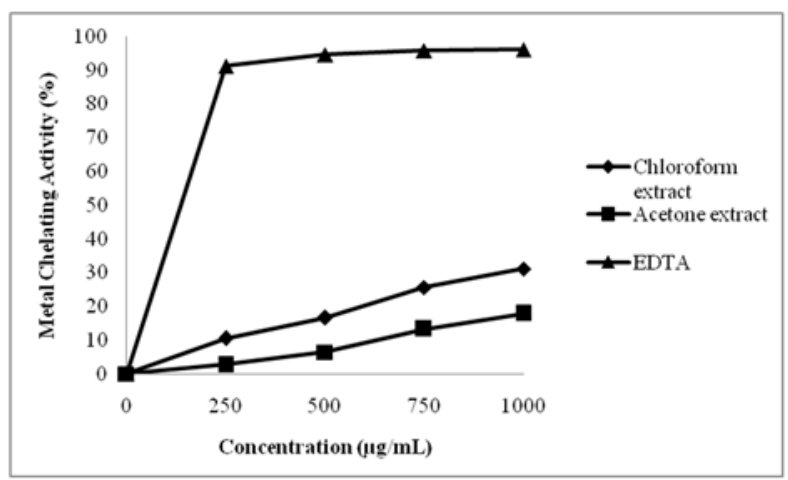

Figure 4. Iron chelating property of extracts of $X$. stenophylla and standard

Fig 4 demonstrates the chelating abilities of $X$. stenophylla samples. When extracts of $X$. stenophylla lichen are compared with EDTA which was used as standard antioxidant, EDTA has higher metal chelating activity than extracts of $X$. stenophylla. Chloroform extract of $X$. stenophylla 
has higher metal chelating activity than acetone extract of $X$. stenophylla.

Both of $X$. stenophylla extracts exhibited DPPH radical scavenging activity, ABTS radical scavenging activity, reducing power and metal chelating activity in all the concentrations. DPPH radical scavenging activity, $A B T S$ radical scavenging activity, reducing power and metal chelating activity of tested lichen extracts are linked with concentration and increases with increasing amounts of samples.

The extraction of biologically active compounds from plant samplesis vigorously affected from the solubility of every particular structure in the solvent utilized. Additionally, the polarity of the solvent and other features have an essential role in raising the solubility of these bioactive matters (Chiste et al., 2013).

There are some surveys on the antioxidant activities of this species, which have been done by other researchers.

Odabaşoğlu et al. (2005) pointed out that methanol extract of $X$. somloensis which is synonym of $X$. stenophylla prevented the lipid peroxidation, but its chloroform extract exhibited mild antioxidant activity and its water extract acted as a prooxidant.

Similarly, Aslan et al. (2011) examined to the antioxidative activity (superoxide dismutase, glutathione peoxidase and malondialdehyde activities) of methanol extracts of $X$. somloensis which is synonym of $X$. stenophylla. It was found that methanol extract of lichen possess strong antioxidative activity.

Antioxidant activity of other Xanthoparmelia species was studied. For example, Paz et al. (2010) studied antioxidant activity of Xanthoparmelia conspersa and Xanthoparmelia camtschadalis lichens via ROS production and ORAC assays. It was found that both of lichen reduced ROS production.

Candan et al. (2005) investigated antimicrobial activity of Xanthoparmelia pokoryni and its gyrophoric and stenosporic acid constituents. Both the extracts and acids showed antimicrobial activity against bacteria and fungi but they were inactive against the tested filamentous fungi.

Undesirable environmental conditions like excess temperature, heavy metals, aridness, pollutants, nutrient inadequacy may raise ROS production (Gill and Tuteja, 2010).

\section{Conclusion}

Our examination affirms that acetone and chloroform extracts of $X$. stenophylla have antibacterial and antioxidant activity. Advanced comprehensive analysies are essential for revealing antioxidative and antibacterial compounds existing in lichens.

\section{References}

Sen, S., Chakraborty, R., Sridhar, C., Reddy, Y.S.R. and De, B., 2010. Free radicals, antioxidants, diseases and phytomedicines: current status and future prospect. International journal of Pharmaceutical Sciences Review and Research, 3(1), 91-100.

Mates, J.M., 2000. Effects of antioxidant enzymes in the molecular control of reactive oxygen species toxicology. Toxicology, 153 (2000): 83-104.

Akinsulure, O.R., Aibinu, I.E., Adenipekun, T., Adelowotan, T. and Odugbemi, T., 2007. In vitro antimicrobial activity of crude extracts from plants Bryophyllum pinnatum and Kalanchoe crenata. African Journal of Traditional, Complementary and Alternative Medicines, 4(3), 338-344.

Srivastava, P., Logesh, A.R., Upreti, D.K., Dhole, T.N. and Srivastava, A., 2013. In vitro evaluation of some Indian lichens against human pathogenic bacteria. Mycosphere, 4(4), 734-743. 
Pavithra, G.M., Vinayaka, K.S., Rakesh, K.N., Junaid, S., Dileep, N., Prashith, K.T.R. and Siddiqua, S., 2013. Antimicrobial and antioxidant properties of macrolichen Usnea pictoides G. Awasthi (Parmeliaceae). Journal of Applied Pharmaceutical Sciences, 3(8), 154-160.

Thippeswamy, B., Sushma, N.R. and Naveenkumar, K.J., 2013. Evaluation of antimicrobial property of lichen Parmelia perlata. African Journal of Pharmacy and Pharmacology, 7(20), 1242-1250.

Vattem, D.A., Vaden, M., Jamison, B.Y. and Maitin, V., 2012. Antioxidant and anti-adhesive activity of some common lichens. Journal of Pharmacology and Toxicology, 7(2), 96-103.

Brodo, I.M., Sharnoff, S.D., Sharnoff, S., 2001. Lichens of North America, Yale University Press, 795 p.,London.

Haq, M.U., Reshi, Z.A., Upreti, D. K. and Sheikh, M.A., 2012. Lichen wealth of Jamnu and Kashmir- a promosing plant source for

Bioprospection. bioprospection. Life Science Journal, 9(4), 926-929.

Kumar, S., Dhankhar, S., Arya, V. P., Yadav, S. and Yadav, J. P., 2012. Antimicrobial activity of Salvadora oleoides Decne. against some microorganisms. Journal of Medicinal Plants Research, 6 (14): 2754-2760.

Dinis, T.C.P., Madeira, V.M.C. and Almeida, L.M., 1994. Action of phenolic derivatives (acetoaminophen, salycilate and 5aminosalycilate) as inhibitors of membrane lipid peroxidation and its peroxyl radical scavengers.

Archieves of Biochemistry and Biophysics, 315: 161-169.

Albayrak, A., 2006. Ceviz yaprakları özütleri ve juglonun bazı mikroorganizmalar üzerine etkisi. Master Thesis, Dumlupınar University, Institue of Science, Kütahya, 35.

Sen, A. and Batra, A., 2012. Evaluation of antimicrobial activity of different solvent extracts of medicinal plant: Melia azedarach L. Atanossova, M., Georgieva, S. and Ivancheva, K., 2011. Total phenolic and total flavonoid contents, antioxidant capacity and biological contaminants in medicinal herbs. Journal of University of
Bauer, A.W., Kirby, W.M., Scherris, J.C., and Turck, M., 1996. Antibiotic susceptibility testing by a standardized single disc method. American Journal of Clinical Pathology, 45, 493-496.

Yiğit, D., Yiğit, N., Aktaş, E. and Özgen U., 2009. Ceviz (Junglans regia L.)' in antimikrobiyal aktivitesi. Türk Mikrobiyoloji Cemiyeti Dergisi, 39 (1-2): 711.

Slinkard, K. and Singleton, V. L., 1977. Total phenol analysis: automation and comparison with manual methods. American Journal of Enology and Viticulture, 28, 49-55.

Zhishen, J., Mengcheng, T. and Jianming, W., 1999. The determination of flavonoid contents in mulberry and their scavenging effects on superoxide radicals. Food Chemistry, 64: 555-559.

Blois, M.S., 1958. Antioxidant determinations by the use of a stable free radical.Nature, 26: 1199-1200.

Arnao, M. B., Cano, A. and Acosta, M., 2001. The hydrophilic and lipophilic contribution to total antioxidant activity. Food Chemistry, 73: 239244.

Oyaizu, M., 1986. Studies on product of browning reaction prepared from glucoseamine. Japanese Journal of Nutrition, 44: 307-315.

International Journal of Current Pharmaceutical Research, 4(2): 67-73.

Houshyar, F., Jamshidi, S. and Sohrabi, M., 2014. Antimicrobial in vitro and in vivo potential of five lichen species on Fusarium equiseti and Pectobacterium carotovora pv. carotovora. International Journal of Advanced Biological and Biomedical Research, 48(4), 412-417.

Zambare, V., Zambare, A. and Christopher, L., 2010. Antioxidant and antibacterial activity of extracts from lichen Xanthoparmelia somloensis, native to the Black hills, South Dakota, USA. International Journal of Medical Science and Technology, 3(2): 46-51.

Chemical Technolog and Metallurgy, 46(1): 8188.

Jeetendra, N. and Manish, B., 2011. Correlation of antioxidant activity with phenolic content and isolation of antioxidant compound from 
Lygodium flexuosum (L.) SW. extracts. International Journal of Pharmacy and Pharmaceutical Sciences, 3(2): 48-52.

Piluzza, G. and Bullitta, S., 2011. Correlations between phenolic content and antioxidant properties in twenty four plant species of traditional ethnoveterinary use in the Mediterranean area. Pharmaceutical Biology, 49(3): 240-247.

Rekika, D., Khanizadeh, S., Deschenes, M., Levasseur, A., Charles, M.T., Tsao, R. and Yang, R., 2005. Antioxidant capacity and phenolic content of selected strawberry genotypes. HortScience 40(6): 1777-1781.

Aksoy, L., Kolay, E., Ağılönü, Y., Aslan, Z. and Kargıoğlu, M., 2013. Free radical activity, total phenolic content, total antioxidant status of endemic Thermopsis turcica. Saudi Journal of Biological Sciences, 20(3): 235-239.

Kumar, J., Dhar, P., Tayade, A.B., Gupta, D., Chaurasia, O.P., Upreti, D.K., Arora, R. and Srivastava, R.B., 2014. Antioxidant capacities, phenolic profile and cytotoxic effects of saxicolous lichens from Trans-Himalayan cold desert of Ladakh. Plos One, 9(6),1-19.

Gordon, M.H. 1990. The Mechanism of Antioxidant Action in vitro, pp. 1-18. In: Hudson, B.J.F. (Editor), Food Antioxidants. Elsevier Science Publishers, London, New York, pp. 309.

Ebrahimzadeh, M. A, Pourmorad, F. and Bekhradnia, A. R., 2008. Iron chelating activity, phenol and flavonoid content of some medicinal plants from Iran. African Journal of Biotechnology, 7(18): 3188-3192.

Chiste, R.C., Benassi, M.T. and Mercadante, A.Z., 2013. Efficiency of different solvents on the extraction of bioactive compounds from the Amazonian fruit Caryocar villosum and the effect on its antioxidant and colour properties. Phytochemical Analysis, 25 (4): 364-372.

Odabaşoğlu, F., Aslan, A., Çakır, A., Çalık, Z.Z. and Süleyman, H., 2005. Xanthoparmelia somloensis'in kloroform, su ve metanol ekstrelerinin in vitro antioksidan potansiyeli ve su ekstresinin ratlarda indometazin ile oluşturulan ülser modeli üzerine gastroprotektif etkisi. 19. Ulusal Biyokimya Kongresi, Antalya, 126-127.

Aslan, A.,Agar, G., Alpsoy, L., Kotan, E. and Ceker, S., 2011. Protective role of methanol extracts of two lichens on oxidative and genotoxic damage caused by $A F B_{1}$, in human lymphocytes in vitro. Toxicology and Industrial Health, 28(6): 505-512.

Paz, G.A., Raggio, J., Gomez-Serranillos, M.P., Palomino, O.M., Gonzalez-Burgos, E., Carretero, M.E. and Crespo, A., 2010. HPLC isolation of antioxidant constituents from Xanthoparmelia spp. Journal of Pharmaceutical and Biomedical Analysis, 53(2): 165-171.

Candan, M., Yılmaz, M., Tay, T., Kıvanç, M. and Türk, H., 2005. Antimicrobial activity of extracts of the lichen Xanthoparmelia pokoryni and its gyrophoric and stenosporic acid constituents. Z. Naturforsch C, 61(5-6): 319-323.

Gill, S.S. and Tuteja, N., 2010. Reactive oxygen species and antioxidant machinery in abiotic stress tolerance in crop plants. Plant Physiology and Biochemistry, 48: 909-930.

internet kaynakları:

1.https://dartpisyper.files.wordpress.com/2015/10/ nccls-manual-m100-s12.pdf (02.11.2015) 